\begin{tabular}{|c|l|}
\hline Title & Spatial distribution of greenhouse gas concentrations in arid and semi-arid regions : A case study in East A sia \\
\hline Author(s) & Guo, M.; Wang, X.-F.; Li, J.; Y i, K.-P.; Zhong, G.-S.; W ang, H.-M.; Tani, H. \\
\hline Citation & $\begin{array}{l}\text { Journal of A rid Environments, 91, 119-128 } \\
\text { https://doi.org/L0.1016/.jaridenv.2013.01.001 }\end{array}$ \\
\hline Issue Date & 2013.04 \\
\hline Doc URL & http://hdl.handle.net/2115/52602 \\
\hline Type & article (author version) \\
\hline File Information & Spatial distribution_rev.pdf \\
\hline
\end{tabular}

Instructions for use 


\title{
Spatial distribution of greenhouse gas concentrations in arid and semi-arid regions: A case study in East Asia
}

\author{
Meng Guo ${ }^{\mathrm{a}, *}$, Xiu-Feng Wang ${ }^{\mathrm{b}}$, Jing Li ${ }^{\mathrm{c}}$, Kun-peng $\mathrm{Yi}^{\mathrm{a}}$, Guo-sheng Zhong ${ }^{\mathrm{a}}$, Hong-Mei Wang ${ }^{\mathrm{d}}$, Hiroshi Tani ${ }^{\mathrm{b}}$, \\ ${ }^{a}$ Graduate School of Agriculture, Hokkaido University, Hokkaido 060-8589, Japan \\ ${ }^{b}$ Research Faculty of Agriculture, Hokkaido University, Hokkaido 060-8589, Japan \\ ${ }^{c}$ Northeast Institute of Geography and Agricultural Ecology, Chinese Academy of Science, Jilin 130012, China \\ ${ }^{d}$ Institute of Public Administration, South China Agricultural University, Guangzhou 510642, China
}

*Corresponding author. Tel: +81-11-706-4174.

E-mail: guomeng1981@gmail.com

\begin{abstract}
:
Land degradation and global warming are currently highly active research topics. Land degradation can both change land cover and surface climate and significantly influence atmospheric circulation. Researches have verified that carbon dioxide $\left(\mathrm{CO}_{2}\right)$ and methane $\left(\mathrm{CH}_{4}\right)$ are major greenhouse gases $(\mathrm{GHG})$ in the atmosphere and are directly affected by human activity. However, to date, there is no research on the spatial distribution of GHG concentrations and also no research on how land degradations affect GHG concentrations in arid and semi-arid regions. In this study, we used GHG data from the ENVIronment SATellite (ENVISAT) and the Greenhouse gases Observing Satellite (GOSAT), the Normalized Difference Vegetation Index (NDVI) and Land Surface Temperature (LST) data from the MODerate resolution Imaging Spectroradiometer (MODIS) and precipitation data from ground stations to analyze the way land degradation affects GHG concentrations in northern China and Mongolia, which exhibit the most serious land degradation process in East Asia. Our research revealed that the $\mathrm{CO}_{2}$ and $\mathrm{CH}_{4}$ concentrations $\left(\mathrm{XCO}_{2}\right.$ and $\left.\mathrm{XCH}_{4}\right)$ increased from 2003 to 2009 and then decreased into 2011. We used geostatistics to predict and simulate the spatial distribution of $\mathrm{XCO}_{2}$ and $\mathrm{XCH}_{4}$ and found that the distribution of $\mathrm{XCO}_{2}$ displays a seasonal trend and is primarily affected by plant photosynthesis, soil respiration and precipitation. As the distribution of $\mathrm{XCH}_{4}$ is mainly affected by the sources' distribution, microbial processes, LST and submarine hydrate, the $\mathrm{CH}_{4}$ concentration presents no obvious seasonal changes and the high $\mathrm{XCH}_{4}$ values are primarily found in northeast and southeast China. Land degradation increases the concentration of GHG: the correlation coefficient between NDVI and $\mathrm{XCO}_{2}$ is $\mathrm{R}^{2}=0.76(\mathrm{P}<0.01)$ and the value between NDVI and $\mathrm{XCH}_{4}$ is $\mathrm{R}^{2}=0.75(\mathrm{P}<0.01)$.
\end{abstract}

Keywords: Climate change; GHG concentrations; Land degradation; Spatial distribution; East Asia 


\section{Introduction}

Climate change is one of the great challenges of the 21st century (IPCC, 2011); the average surface temperature has increased by $0.74{ }^{\circ} \mathrm{C}$ over the past 100 years (1906-2005). The increasing concentration of greenhouse gases (GHG) in the atmosphere has been verified as the most important reason for global warming, which is a major environmental concern and a prominent research topic (Wu and Shi, 2011; Zhang et al., 2005). According to the analysis of the World Data Centre for Greenhouse Gases (WDCGG, http://gaw.kishou.go.jp/wdcgg/wdcgg.html), the average global $\mathrm{CO}_{2}$ concentration $\left(\mathrm{XCO}_{2}\right)$ in 2010 was $389.0 \mathrm{ppm}$, which is $11.9 \mathrm{ppm}$ more than in 2004; this figure has increased 39\% from the pre-industrial global level of $280.0 \mathrm{ppm}$. The average $\mathrm{CH}_{4}$ concentration $\left(\mathrm{XCH}_{4}\right)$ was $1808 \mathrm{ppb}$ in 2010, which represents an increase of $158 \%$ from approximately $700 \mathrm{ppb}$ in the pre-industrial era (WMO Greenhouse Gas Bulletin, 2004-2010).

Current GHG emission rates may escalate in the future due to population growth and changing diets. Wu and Shi (2011) recognized that the rapid development of the tourism industry can also increase the emission of GHG. Land degradation caused by unviable agricultural practices is another source of increased GHG emissions (Dutt and Gonzalez, 2011).

The degradation of vegetation and soils in drylands, also referred to as desertification, is thought to be a serious threat to the sustainability of human habitation. The reduction in vegetation cover that accompanies desertification has also led to soil erosion (Hassan, 2004). The rise in global atmospheric temperatures may also increase the frequency of droughts in the middle latitudes during the summer months ( $\mathrm{Ci}$ and Yang, 2010). The land degradation through unviable agricultural practices and land use has also resulted in the increased emission of GHG (Hulme and Kelly, 1993).

Climate change may adversely affect biodiversity and exacerbate desertification due to increases in evapotranspiration and likely decreases in rainfall in drylands. However, because $\mathrm{CO}_{2}$ is the raw material of photosynthesis and is also a major resource for plant productivity, efficient water use in arid and semi-arid areas will significantly increase for some dryland species that may respond favorably to increases in $\mathrm{CO}_{2}$. The contrasting responses of different dryland plants to increasing $\mathrm{CO}_{2}$ and temperatures may lead to changes in the species' composition and abundance (Zafar et al., 2005).

An adequate understanding of the sources and sinks of GHG and their feedbacks is a prerequisite for the reliable prediction of the climate of our planet. However, our current understanding of this is inadequate due to the lack of accurate time-series data. While measurements of fluxes and ground-based measurements of $\mathrm{CO}_{2}$ and $\mathrm{CH}_{4}$ are highly accurate, they are sparse and inefficient. Launching satellites to collect GHG data can solve this issue quite well. At present, SCIAMACHY (SCanning Imaging Absorption spectroMeter for Atmospheric CHartographY) aboard ENVISAT (ENVIronmental SATellite), launched in 2002 but lost in April 2012, and TANSO (Thermal And Near infrared Sensor for carbon Observation) aboard GOSAT (Greenhouse gases Observing SATellite), 
launched in 2009, are the instruments measuring NIR radiation in appropriate absorption bands at approximately 0.76, 1.6, and $2.0 \mu \mathrm{m}$, with sufficient spectral resolutions to retrieve $\mathrm{XCO}_{2}$ and $\mathrm{XCH}_{4}$ (Reuter et al., 2010).

Due to the infrequency of sustained periods of carbon uptake, there is no research on the spatial distribution of GHG concentrations in arid and semi-arid regions based on remote sensing data for that time frame. To fill this gap, the aims of this study were as follows: first, to analyze changes in $\mathrm{XCO}_{2}$ and $\mathrm{XCH}_{4}$ from 2003 to 2011 using ENVISAT SCIAMACHY and GOSAT TANSO data; second, to analyze the spatial distributions of $\mathrm{XCO}_{2}$ and $\mathrm{XCH}_{4}$ in the study area in 2010 based on the TANSO data and using the Ordinal Kriging method; and finally, using Normalized Difference Vegetation Index (NDVI) data from the MODerate resolution Imaging Spectroradiometer (MODIS) combined with precipitation data and land surface temperature (LST) data to analyze the spatial distribution of GHG concentrations. We know that human activities are the most important source of GHG (IPCC, 2011). However, here we will only discuss the relationships between NDVI and GHG concentrations.

\section{Data and Methods}

\subsection{Study region}

The study area was located in East Asia between $30^{\circ}-50^{\circ} \mathrm{N}$ and $73.5^{\circ}-134.5^{\circ} \mathrm{E}$, covering approximately $7.46 \times 10^{6}$ $\mathrm{km}^{2}$ of northern China and Mongolia (Fig. 1. The regions that covered by land cover data are the study area). This region exhibits the most serious desertification in East Asia. It is also one of the areas most highly prone to sand dust storms in Asia (Guo et al., 2012).

In China, the area of desertification is $2.62 \times 10^{6} \mathrm{~km}^{2}$, accounting for $27.31 \%$ of all terrestrial land. Nearly all of China's desertified land (including the Gobi desert) is located in the north and west of the country. In addition to natural changes in climate, the increased temperature and decreased precipitation over northern China brought on by land degradation could alter the northern Chinese climate from a light drought to a severe drought (Zhang et al., 2005). According to meteorological records, the temperature in northern China has shown an increasing trend and a significant reduction in precipitation. Droughts, especially serious droughts, often cause a reduction in agricultural productivity, a water resources crisis and even serious sand dust storms. According to incomplete statistics, since 1960, Northern China has experienced 13 periods of serious drought (Ci and Yang, 2010).

In Mongolia, the area of desertification is approximately $6.4 \times 10^{5} \mathrm{~km}^{2}$, accounting for $41 \%$ of all the terrestrial land of Mongolia. Mongolia is also the origin of the "cold current" in Asia and Europe. Precipitation is highest in the north, which averages 200 to $350 \mathrm{~mm}$ per year, and lowest in the south, which receives 10 to $20 \mathrm{~mm}$ per year. The Gobi desert can be found in the extreme south, where some regions often receive no precipitation at all. 


\subsection{Data}

\subsubsection{ENVISAT SCIAMACHY Data}

The SCIAMACHY instrument is part of the atmospheric chemistry payload of the European Space Agencies (ESA) environmental satellite ENVISAT, launched in March 2002. SCIAMACHY is a grating spectrometer, which is a multinational (Germany, The Netherlands and Belgium) contribution to ENVISAT, measuring reflected, backscattered and transmitted solar radiation in the spectral region of 214-2380 $\mathrm{nm}$. The spectral near-infrared nadir measurements of the SCIAMACHY instrument are sensitive to concentration changes in the two most important $\mathrm{GHG}, \mathrm{CO}_{2}$ and $\mathrm{CH}_{4}$, at all atmospheric altitude levels including the boundary layer, where the surface source signal is the highest (Schneising et al., 2011).

In contrast to TANSO, SCIAMACHY was not specifically designed for the retrieval of GHG concentrations. As a result of SCIAMACHY's coarser spatial and spectral resolution, the achievable accuracy is expected to be lower. Nevertheless, between the years 2002 and 2009, SCIAMACHY was the only satellite instrument measuring $\mathrm{XCO}_{2}$ and $\mathrm{XCH}_{4}$ with significant sensitivity in the boundary layer. Long-term (2003-2009) global $\mathrm{CO}_{2}$ and $\mathrm{CH}_{4}$ dry air column-averaged mole fraction data sets from SCIAMACHY derived using the Weighting Function Modified DOAS (WFM-DOAS) developed at the University of Bremen were used in this study.

\subsubsection{GOSAT TANSO FST L2 data}

GOSAT was launched on January 23, 2009 by the Japanese Space Agency. It is the world's first spacecraft designed to measure the concentrations of $\mathrm{CO}_{2}$ and $\mathrm{CH}_{4}$ from SWIR bands with global coverage every 3 days. GOSAT is a sun-synchronous orbit with a local overpass time of 13:00 (Parker et al., 2011). It is a joint project of the Japan Aerospace Exploration Agency (JAXA), the Ministry of the Environment (MOE) and the National Institute for Environmental Studies (NIES).

As we know, molecules of $\mathrm{CO}_{2}$ and $\mathrm{CH}_{4}$ in the atmosphere absorb light of particular wavelengths. GOSAT used this theory to measure the concentrations of $\mathrm{CO}_{2}$ and $\mathrm{CH}_{4}$ in the atmosphere. The primary purpose of the GOSAT project is to accurately estimate the emissions and absorptions of GHG on a subcontinental scale, to assist environmental administrations in evaluating the carbon balance of land-based ecosystems, and to provide assessments of regional emissions and absorptions (GOSAT Project homepage: http://www.gosat.nies.go.jp/eng/gosat/info.htm).

The GOSAT project has released FST (Fourier Transform Spectrometer) global GHG concentration data (L3 data), but because their coarse resolution $\left(2.5^{\circ} \times 2.5^{\circ}\right)$ omits a great deal of information, GOSAT FTS SWIR L2 (store column abundances of $\mathrm{CO}_{2}$ and $\mathrm{CH}_{4}$ retrieved from the radiance spectra in bands 1 through 3 of FTS) data from 2010 and 2011 were used in this study. The data of GOSAT FTS SWIR L2 are point data; thus, we obtained 
the GHG concentration distribution map using the method of interpolation described below. At last, the seasonal distributions of $\mathrm{CO}_{2}$ and $\mathrm{CH}_{4}$ concentrations with spatial resolution of $0.05^{\circ}$ were obtained.

\subsubsection{MODIS NDVI data}

In arid conditions, vegetation provides protection against degradation such as wind/water erosion. Vegetation reflects the hydrological and climate variations of the dry ecology. Decreasing vegetation cover and changes in the species composition of vegetation are sensitive indicators of land degradation (Haboudane et al., 2002). Elhadi and Zomrawi (2010) argued that vegetation index is a primary indicator of land cover changes in arid and semi-arid regions. The index of vegetation includes many different methods of expression; among them, NDVI has been considered as one of the most important indices used to assess and monitor desertification, land degradation and rangeland changes in arid or semi-arid regions (Wessels et al., 2004).

The NDVI data used in this study are the MODIS products of MOD13A1. They are 16-day grid data with a horizontal resolution of $500 \mathrm{~m}$ by $500 \mathrm{~m}$, produced by the Earth Observation System (EOS) NASA. The MOD13A NDVI accuracy is within \pm 0.025 and the accuracy for a good quality day (high quality without the nadir view requirement) would be within \pm 0.020 . Errors in the red band associated with residual atmospheric effects are the main source of the NDVI errors (Gao et al., 2003). The study area is located in the high latitudes with snowy winters. In this study, we used the maximum value (Fensholt and Proud, 2012) composite of all the NDVI data of the Julian calendar days 161 to 257 (Fig. 2).

\subsubsection{MODIS LST data}

The LST is retrieved from MODIS thermal bands data (band 31 and 32) over the entire land surface of the earth. The required surface emissivity in bands 31 and 32 are estimated from land cover types (Langer et al., 2010). The LST is derived from the energy balance at the soil-atmosphere interface and is therefore a crucial parameter for the environmental energy budget (Langer et al., 2010; Wan, 2008). It is a good indicator of the ground surface energy balance and the so-called greenhouse effect, as it is one of the key parameters in the physics of land-surface processes at regional and global scales (Wan, 1999). The LST is the result of the surface-atmosphere interactions and energy fluxes between the atmosphere and ground surface; therefore, it is widely used in climate, hydrologic, ecological and biogeochemical studies (Hengl et al., 2012). MODIS Terra LST Monthly L3 Version 041 with a resolution of $0.05^{\circ}$ (MOD11C3) was used in this study (Fig. 3). The MODIS LST accuracy is within $1 \mathrm{~K}$ in the range from 263 to $322 \mathrm{~K}$ under clear-sky conditions (Momeni and Saradjian, 2007).

\subsubsection{Meteorological data}

The precipitation data of China and Mongolia used in present study were downloaded from the website of the China Meteorological Data Sharing Service System (http://cdc.cma.gov.cn) and Weather History and Data Achieve (http://www.wunderground.com/history), respectively. In total, 188 ground stations in China and 26 in Mongolia 
were used to calculate the annual precipitation from 2003 to 2011. The annual precipitations were used to analyze how climatic factors affect the NDVI in arid and semi-arid regions and how annual precipitations affect GHG concentrations. We also used these data to map the spatial distribution of precipitation in 2010 (Fig.4).

\subsection{Methods}

The Kriging interpolation is an important geostatistics methods based on the variogram. A variogram is a geostatistical technique which can be used to examine the spatial continuity of a regionalized variable and how this continuity changes as a function of distance and direction. For a detailed description of Kriging interpolation, please see the paper by Schneider et al. (2008).

As outliers create artifacts during interpolation, in order to get better results of interpolation surface we should remove the outlier values of each season. The outliers contain global outliers and local outliers: we can use normal QQPlot tool in ArcGIS 10 to check whether the data conform to the normal distribution or not and find out the global outliers. Semivariograms were constructed and fitted to curve types. Outliers are the sample points that with small distance but large variation, the outliers are distribute in the upper left corner of the Semivariograms cloud map (http://help.arcgis.com/en/arcgisdesktop/10.0/help/index.html). Each season, we selected different semivariogram models and different parameters, determined the best-fit model and parameters through multiple calculations and comparative analyses.

There are 1902 points of $\mathrm{CO}_{2}$ and 1871 points of $\mathrm{CH}_{4}$ from March 2010 to February 2011 covered the study area. Because some points overlap, several points must be deleted to ensure that there was no overlap point and that the point distribution was regular. To this end, we created a fishnet of squares measuring $0.5^{\circ} \times 0.5^{\circ}$ to cover the study area using ArcGIS. We used the mean value of all the points in one square as the value for that square; because the fishnet is a polygon file, to use the Ordinary Kriging method, we covert the fishnet into points using the Data Management Tools of ArcGIS 10. After this process, there remained 578 points of $\mathrm{XCO}_{2}$ and 574 points of $\mathrm{XCH}_{4}$, and these points were distributed evenly across the study area.

\section{Results and discussion}

\subsection{Annual changes of GHG concentrations in East Asia}

We calculated the annual value of GHG concentrations using SCIAMACHY and TANSO from 2003 to 2011. Fig. 5 demonstrates that $\mathrm{XCO}_{2}$ and $\mathrm{XCH}_{4}$ increased from 2003 to 2009 and then clearly decreased until 2010. $\mathrm{XCH}_{4}$ continued to decrease but $\mathrm{XCO}_{2}$ exhibited a small increase between 2010 and 2011. The significant turning point appears in 2010; this is primarily due to the different levels of precision of SCIAMACHY and TANSO. The evaluated precisions of the retrieved column abundances for the single observations of GOSAT are less than 1.00\% 
in most cases (Yoshida et al., 2011). To check the accuracy of the SCIAMACHY WFM-DOAS data set, we selected two ground stations named Mt. Waliguan in China and Ulaan Uul in Mongolia from WDCGG. Mt. Waliguan $\left(36.28^{\circ} \mathrm{N}, 100.90^{\circ} \mathrm{E}, 3810 \mathrm{~m}\right.$ ), situated in remote western China (Fig. 1), is one of the 26 World Meteorological Organization (WMO)/Global Atmosphere Watch (GAW) global baseline stations. It is located at the edge of the northeastern part of the Tibetan Plateau. The area surrounding the station is pristine with sparse vegetation, mostly arid and semiarid grassland. Ulaan Uul $\left(44.45^{\circ} \mathrm{N}, 111.08^{\circ} \mathrm{E}, 914 \mathrm{~m}\right)$ located in the east south side of Mongolia (Mongolian dessert-steppe region) far from any anthropogenic sources.

Table 1 shows that the accuracies of $\mathrm{XCO}_{2}$ are $0.30 \%$ and $0.74 \%$ in Mt. Waliguan and Ulaan Uul, respectively, but the accuracies of $\mathrm{XCH}_{4}$ are $-3.29 \%$ and $-4.12 \%$ in Mt. Waliguan and Ulaan Uul, respectively. We also found that the ground-measured values of $\mathrm{XCO}_{2}$ are lower than those of the data set of SCIAMACHY, and the opposite situation is observed for $\mathrm{XCH}_{4}$.

To understand the monthly changes in GHG concentrations, we calculated the monthly average concentrations of $\mathrm{CO}_{2}$ and $\mathrm{CH}_{4}$ in 2010 from TANSO FST L2 data collected within the study region (the area that covered by land cover image in Fig. 1). Fig. 6 shows that the $\mathrm{CO}_{2}$ concentration varied significantly between months, with the highest concentration of $\mathrm{CO}_{2}$ in March and its lowest concentration in July. The difference between the maximum and minimum concentration is $10.72 \mathrm{ppm}$. From March onward, the temperature increased gradually, the heating from burning fossil fuels lessened and the rate of photosynthesis increased. In addition, plant photosynthesis absorbs $\mathrm{CO}_{2}$ during this period, leading to decreases in the $\mathrm{XCO}_{2}$ levels between March and July. From July to October, plant photosynthesis decreased, the soil emission $\mathrm{CO}_{2}$ increased with the increasing temperature and soil moisture, and the concentration of $\mathrm{CO}_{2}$ in the atmosphere increased (Oechel et al., 1995). Starting in October, decreasing temperatures led to weaker soil respiration. Moreover, plant photosynthesis disappears in Mongolia and northern China, causing increases in $\mathrm{CO}_{2}$ concentration. The increased burning of fossil fuels in winter is also an important factor contributing to increases in the $\mathrm{CO}_{2}$ concentration.

After $\mathrm{CO}_{2}, \mathrm{CH}_{4}$ is the most important anthropogenic GHG. It also has an indirect effect on climate through chemical feedback. More than $50 \%$ of present-day global $\mathrm{CH}_{4}$ emissions are anthropogenic; the largest contributors are fossil fuel production, ruminant animals (e.g., cows or sheep), rice cultivation and waste handling (Frankenberg et al., 2005). Fig. 6 shows that the $\mathrm{CH}_{4}$ concentration in the atmosphere ranges from $1724.26 \mathrm{ppb}$ in May to $1775.05 \mathrm{ppb}$ in September. Wetlands are among the primary sources of atmospheric $\mathrm{CH}_{4}$, while flooded rice fields and peatlands are also substantial sources (Ojanen et al., 2010). The $\mathrm{CH}_{4}$ concentration increased due to rice cultivation in May; after the rice harvest in September, the concentration reduced. Keppler et al. (2006) found that the emission of $\mathrm{CH}_{4}$ was temperature sensitive. Therefore, the increasing temperature between May and September is another reason for the increased concentration of $\mathrm{CH}_{4}$. When landscapes are flooded to create any kind of reservoir, terrestrial plants die and no longer assimilate $\mathrm{CO}_{2}$ by photosynthesis. Bacteria decompose the organic carbon that was stored in the plants and soils, converting it to $\mathrm{CH}_{4}$, which are then released into the atmosphere 
(Louis et al., 2000). In East Asia, the rainfall is mainly focused in June, July and August, so $\mathrm{CH}_{4}$ concentrations are high in these months. Beginning in September, as the temperature began to decrease, the $\mathrm{CH}_{4}$ emissions decreased as well, and the overall $\mathrm{CH}_{4}$ concentration displayed a downward trend.

\subsection{NDVI changes in arid and semi-arid regions of East Asia}

NDVI is an ideal indicator of vegetation biomass activity and parameters such as temperature, precipitation and other climatic variables are necessary to explain the variance exhibited by the NDVI (Chen et al., 2012). Many scholars used NDVI to study desertification at a global and regional scale: Bai et al. (2008) combined NDVI trends with rain-use efficiency as a proxy for desertification at the global scale. Elmzoughi et al. (2008) demonstrated the possibility of using only long term, minimum NDVI time-series data, without precipitation data, to assess the level of desertification in southern Tunisia.

In this study, we used NDVI from MODIS Terra to calculate the vegetation changes from 2003 to 2011 in East Asia. The maximum NDVI values of the Julian calendar days 161 to 257 for each year were used. An increase in NDVI indicates an increasing in vegetation cover, and vice versa. Fig. 7 shows that vegetation fluctuates. The difference between the maximum and minimum NDVI is 0.017 NDVI unites. Vegetative production in arid and semi-arid regions is closely related to the long-term average precipitation and inter-annual rainfall variability (Elhag, 2006; Rutherford, 1980). The NDVI has been empirically shown to relate strongly to green vegetation cover and biomass using ground-based studies involving spectral radiometers (Stellmes et al., 2010). We select 214 ground stations over the study area to check the relationships between desertification and annual precipitation. From Fig. 7 we can found that the NDVI have the similar trend with precipitation from 2003 to 2010 but the slopes are different because of other factors effect. In 2011, the trends of NDVI and annual precipitation are opponent, which maybe because of uneven seasonal distribution of precipitation.

\subsection{Impact of NDVI on GHG concentrations}

Atmospheric $\mathrm{XCO}_{2}$ variations over the long term have been caused by several geochemical processes. $\mathrm{CO}_{2}$ is removed from the atmosphere primarily through green plants photosynthesis. In serious cases of land degradation, the $\mathrm{CO}_{2}$ concentration increases due to a lack of $\mathrm{CO}_{2}$ sink. Land degradation in arid and semi-arid regions that accompanied by the degradation of vegetation and organic soil can lead to drought and high temperature $(\mathrm{Ci}$ and Yang, 2010), which can also result in increases in $\mathrm{CO}_{2}$ concentrations. The sources of $\mathrm{CH}_{4}$ are primarily rice fields, wetlands and peatlands, and the amount of $\mathrm{CH}_{4}$ emission is also affected by temperature and soil moisture (Inubushi et al., 2003). To examine how land cover changes effect GHG concentrations in arid and semi-arid regions of East Asia, we calculated the relationships between NDVI and GHG concentrations. 
Fig. 8 demonstrates that with the increases in NDVI, $\mathrm{CO}_{2}$ and $\mathrm{CH}_{4}$ concentrations decrease. The correlation coefficient between NDVI and $\mathrm{XCO}_{2}$ is $\mathrm{R}^{2}=0.76(\mathrm{P}<0.01)$, the value between NDVI and $\mathrm{XCH}_{4}$ is $\mathrm{R}^{2}=0.75$ $(\mathrm{P}<0.01)$. This means that land degradation can result in increases in GHG concentrations. Land degradation that accompanied with vegetation decreasing can decrease the photosynthesis of green plant which increasing the $\mathrm{CO}_{2}$ concentration in atmosphere. In fact, GHG concentrations are also a result of climate changes because of the close relationships between NDVI and precipitation.

Some researchers have found that $\mathrm{CH}_{4}$ can be offset by oxidation, which largely takes place in the atmosphere through reactions with the free radical $(\mathrm{OH})$ (Cicerone and Oremland, 1988; Crutzen and Gidel, 1983; WMO Greenhouse Gas Bulletin, 2010). $\mathrm{OH}$ in the atmosphere is generated photochemically through short-wavelength radiation, such as the reaction of electronically excited $\mathrm{O}$ atoms with $\mathrm{H}_{2} \mathrm{O}$ and organic molecules. The drought and high temperatures that result from land degradation in arid and semi-arid regions can decrease $\mathrm{H}_{2} \mathrm{O}$ in the atmosphere, which affects the formation of $\mathrm{OH}$, increasing the $\mathrm{CH}_{4}$ concentration (Guo et al., 2012).

\subsection{Spatial distribution of GHG concentration in East Asia}

\subsubsection{Seasonal distribution of $\mathrm{CO}_{2}$ concentration}

Fig. 9 shows that the spatial distribution of $\mathrm{CO}_{2}$ concentrations differs between the seasons. The seasonal cycles of the atmospheric GHG concentrations have been shown to be associated with surface air temperatures, which is consistent with the hypothesis that warmer temperatures have promoted increases in biosphere activity outside of the tropics (Myneni et al., 1997).

In spring, higher values occur primarily in northwest China and east of Heilongjiang province. Lower concentrations appear in east Mongolia, west Inner Mongolia and the southwest Xinjiang province. During the spring in China and Mongolia, the $\mathrm{CO}_{2}$ concentration is not affected by the respiration of plants due to a lack of green vegetation but by soil emissions. Soil respiration emits $\mathrm{CO}_{2}$ into the atmosphere when the temperature increases (Oechel et al., 1995). Higher $\mathrm{CO}_{2}$ concentration appears in Qinghai, Tibet and Sichuan province because of higher elevation and lower temperature postpone the vegetation greenup. Higher $\mathrm{CO}_{2}$ concentration also appears in east of Heilongjiang province because of the soil in this region is rich in organic matters (Duan et al., 2001). The $\mathrm{CO}_{2}$ concentration in the south is higher than in the north of the study area due to its temperature sensitivity (Oechel et al., 1995). The $\mathrm{CO}_{2}$ concentrations of east Mongolia, west Inner Mongolia and the Xinjiang province have the lowest values. Comparing these locations with Fig. 1 shows that these regions consist of desert (including the Gobi desert) and sandy land. The amount of $\mathrm{CO}_{2}$ reserved by desert soil is less than that of other soils (Duan et al., 2001); therefore, $\mathrm{CO}_{2}$ emissions from desert areas are lower than from other regions. With increases in temperature (Fig. 3), soil respiration also increases, which can emit $\mathrm{CO}_{2}$ (Sun, 2001). And the increases in 
temperature in the south of China occur more rapidly than in the north of China, causing higher $\mathrm{CO}_{2}$ concentrations in the south of China.

In the summer, $\mathrm{CO}_{2}$ concentrations are affected by two primary factors: respiration from green plants and soil emission. The photosynthesis of plants can convert $\mathrm{CO}_{2}$ into organic compounds, especially sugars, using energy from sunlight. The $\mathrm{CO}_{2}$ concentration in soil is much higher than that of the atmosphere (Chong et al., 2003); therefore, soil is a significant source of $\mathrm{CO}_{2}$. Soil respiration has a clear relationship with temperature and soil moisture; under elevated temperatures and appropriate soil moisture, much of the soil carbon stored in the active layer and entombed in permafrost could be released to the atmosphere, resulting in higher $\mathrm{CO}_{2}$ emissions (Oechel et al., 1995; Schuur et al., 2009). Mielnick et al. (2005) measured the $\mathrm{CO}_{2}$ emission above the Chihuahuan desert grassland from 1996 through 2001 and found that the ecosystem produced a significant amount of $\mathrm{CO}_{2}$ every month. Fig. 9 demonstrates that in the summer, the highest concentrations of $\mathrm{CO}_{2}$ appear in Mongolia, west China and northeast China. In Mongolia and west China, $\mathrm{CO}_{2}$ cannot be absorbed by plants because of the low vegetation cover (Fig. 1) and low precipitation (Fig. 4). In northeastern China, the higher $\mathrm{CO}_{2}$ concentration is mainly because of relatively high LST (Fig. 3) and precipitation (Fig. 4). The amount of $\mathrm{CO}_{2}$ emitted by soil is also affected by the soil type. In northeast China, the soil type is mainly black soil, which is rich in organic matter. Due to the high temperatures in summer, microbial decomposition of the organic matter causes the soil to emit more $\mathrm{CO}_{2}$ (Sun, 2001). The lowest $\mathrm{CO}_{2}$ concentration occurs in central China, primarily due to the high vegetation cover (Fig. 2) absorb $\mathrm{CO}_{2}$ in the atmosphere.

In autumn, which occurs from September to November, the highest $\mathrm{CO}_{2}$ concentrations appear in central China, west of Tibet and the south of northeastern China. The lowest concentrations appear in east Mongolia, Xinjiang province and the Qinghai province. As the photosynthesis of plants disappears in autumn, and the $\mathrm{CO}_{2}$ concentration is mainly affected by soil emission, regions covered by desert and sandy land have low $\mathrm{CO}_{2}$ concentrations, and regions covered by fertile soil have high concentrations of $\mathrm{CO}_{2}$. Precipitation and temperature are also important reasons for the spatial distribution of $\mathrm{CO}_{2}$ concentration in autumn. With the decreasing of temperature, plant photosynthesis decreases. The regions with appropriate soil moisture and higher LST (Fig. 3) emit lots of $\mathrm{CO}_{2}$ to the atmosphere.

In winter, the highest concentration of $\mathrm{CO}_{2}$ is primarily found in central China, and the lowest $\mathrm{CO}_{2}$ concentration appears in the west and northeast of China and the east of Mongolia. Due to a lack of plant photosynthesis, there is no plant photosynthesis, and the soil is frozen in high-latitude regions. The high $\mathrm{CO}_{2}$ concentration is mainly the results of soil respiration in south China.

\subsubsection{Seasonal distribution of $\mathrm{CH}_{4}$ concentration}


Regarding the $\mathrm{CH}_{4}$ concentration in the atmosphere, Fig. 10 shows that the concentration of $\mathrm{CH}_{4}$ ranged from 1704.32 ppb to 1824.77 ppb from March 2010 to February 2011. We found that the highest $\mathrm{CH}_{4}$ concentrations were primarily distributed in southeast and northeast China. In the spring, the lowest concentrations were distributed in Mongolia, Xinjiang and Tibet. In the summer, the lowest concentrations were found in areas of in low vegetation (Fig. 2). In the autumn, the low-concentration areas included Mongolia, Inner Mongolia and western China. In winter, the lowest values were found in the Qinghai province and Tibet, while Mongolia and Inner Mongolia also had low concentrations of $\mathrm{CH}_{4}$.

Wetlands are a significant source of atmospheric $\mathrm{CH}_{4}$. Biogenic $\mathrm{CH}_{4}$ emissions from wetlands are determined by two different microbial processes: $\mathrm{CH}_{4}$ production and $\mathrm{CH}_{4}$ oxidation. $\mathrm{CH}_{4}$ production is mainly controlled by the quality of the soil's organic matter and vegetation, while $\mathrm{CH}_{4}$ oxidation depends strongly on the availability of oxygen. Both processes are influenced by soil temperature and $\mathrm{pH}$ (Schneider et al., 2009). Flooded rice fields and peatlands are also significant sources of $\mathrm{CH}_{4}$ (Jackel et al., 2001; Ojanen et al., 2010). Vegetation roots emit $\mathrm{CH}_{4}$ under aerobic conditions (Frankenberg et al., 2005). Of all the land cover types, drylands emit the smallest amount of $\mathrm{CH}_{4}$ (Jiang et al., 2009). The emission of $\mathrm{CH}_{4}$ from forest, cultivated land, grasslands and other vegetation covers in China accounted for 43.0\%, 28.3\%, 19.0\%, and 9.7\% of all $\mathrm{CH}_{4}$ emissions, respectively (Xie et al., 2008). The largest wetland regions and the main rice production regions of China can be found in the northeast and southeast (Fig. 1). The Sanjiang plain located in northeast Heilongjiang province is the most famous commodity grain base of China and the main crop is rice. Fig. 10 demonstrates that in these areas, the $\mathrm{CH}_{4}$ concentration is typically high.

The $\mathrm{CH}_{4}$ emissions are related to the soil moisture, temperature and soil organic matter quality (Andersen and White, 2006). Keppler et al. (2006) found that the release of $\mathrm{CH}_{4}$ was highly temperature sensitive, and the concentrations approximately doubled with every $10^{\circ} \mathrm{C}$ increase across the range of $30-70^{\circ} \mathrm{C}$. The high precipitation and LST in southeast and northeast China (Fig. 3 and Fig. 4) are other causes for the spatial distribution of high $\mathrm{CH}_{4}$ concentration.

Fig. 10 also shows that the lowest $\mathrm{CH}_{4}$ concentrations are located mainly over desert (e.g., Gobi) and sandy terrain (Fig. 1). Due to its lack of a significant $\mathrm{CH}_{4}$ source, the $\mathrm{CH}_{4}$ concentration in these areas is very low.

\section{Conclusions}

The reduction of GHG emissions arising from land cover change and land degradation-that is, the reduction of emissions from the conversion and degradation of vegetation-is an issue of crucial significance to the future. Therefore, it is important to understand the monthly trends of GHG concentrations and the spatial distribution of these concentrations at a regional scale. This study selected northern China and Mongolia as its study regions. Spaceborne GHG monitoring data were employed to analyze the concentrations of $\mathrm{CO}_{2}$ and $\mathrm{CH}_{4}$ over time from 
2003 to 2011. Moreover, we seasonally mapped the spatial distribution of GHG concentrations in 2010 and quantified the relationships between NDVI and GHG concentration changes. Following these analyses, we present the following conclusions:

(1) In our study area, the concentrations of $\mathrm{CO}_{2}$ and $\mathrm{CH}_{4}$ increased from 2003 to 2009 and then decreased. NDVI changes fluctuate, but have the similar trends with annual precipitation from 2003 to 2010.

(2) The concentrations of $\mathrm{CO}_{2}$ and $\mathrm{CH}_{4}$ in the atmosphere exhibited a monthly trend. The $\mathrm{CO}_{2}$ concentration decreased from March to its minimum value in July and then increased in autumn and winter. $\mathrm{The}^{\mathrm{CH}}$ concentration increased from May to its peak value in September and then decreased.

(3) Land degradation can increase the GHG concentrations. The correlation coefficient between NDVI and $\mathrm{XCO}_{2}$ is $\mathrm{R}^{2}=0.76(\mathrm{P}<0.01)$; the value between NDVI and $\mathrm{XCH}_{4}$ is $\mathrm{R}^{2}=0.75(\mathrm{P}<0.01)$.

(4) We also analyzed the spatial distributions of $\mathrm{CO}_{2}$ and $\mathrm{CH}_{4}$ concentrations and found that the $\mathrm{CO}_{2}$ concentration exhibits evident seasonal changes. Green plant photosynthesis and the respiration of soil emission are the two primary factors affecting $\mathrm{CO}_{2}$ concentrations in the atmosphere. Our analyses also revealed that the highest concentrations of $\mathrm{CH}_{4}$ were found in northeast China and central China. The rice production and wetland regions are the most important factors in determining the concentration of $\mathrm{CH}_{4}$ in northeast China. Due to the lack of a significant $\mathrm{CH}_{4}$ source, the lowest $\mathrm{CH}_{4}$ concentrations are located mainly in the desert (e.g., Gobi) and sandy terrain. Precipitation and LST are also important factors affecting the spatial distributions of GHG concentrations.

\section{Acknowledgements}

This study was supported by National Natural Science Foundation of China (41201159, Study on the effect mechanism of commercial center pattern on traffic carbon emissions in Shenyang city. PI: Assistant Researcher Jing Li, Chinese Academy of Sciences, China). We thank the GOSAT Project of Japan and NASA for the use of their data in this study.

\section{References}

Andersen, S.K., White, D.M., 2006. Determining soil organic matter quality under anaerobic conditions in arctic and subarctic soils. Cold Regions Science and Technology 44, pp. 149-158.

Bai, Z.G., Dent, D.L., Olsson, L., Schaepman, M.E., 2008. Proxy global assessment of land degradation. Soil Use and Management 24(3), 223-234.

Chen, Z.J., Li, J.B., Fang, K.Y., Davi, N.K., He, X.Y., Cui, M.X., Zhang, X.L., Peng, J.J., 2012. Seasonal dynamics of vegetation over the past 100 years inferred from tree rings and climate in Hulunbei'er steppe, northern China. Journal of Arid Environments 83(0), 86-93. 
Chong, S.K., Boniak, R., Chang-Ho, O., Indorante, S., Dinelli, F.D., 2003. How do soils breathe? Golf Course Management 71, 181-183.

Ci, L.J., Yang, X.H., 2010. Desertification and its control in China. Higher Education Press, Beijing, pp.10-19.

Cicerone, R.J., Oremland, R.S., 1988. Biogeochemical aspects of atmospheric methane. Global Biogeochemical Cycles 2, 299327.

Crutzen, P.J., Gidel, L.T., 1983. A Two-dimensional photochemical model of the atmosphere 2: The tropospheric budgets of the anthropogenic chlorocarbons $\mathrm{CO}, \mathrm{CH}_{4}, \mathrm{CH}_{3} \mathrm{Cl}$ and the effect of various $\mathrm{NO}_{\mathrm{x}}$ sources on tropospheric Ozone. Journal of Geophysical Research 88, 6641-6661.

Duan, Z.H., Xiao, H.L., Dong, Z.B., He, X.D., Wang, G., 2001. Estimate of total $\mathrm{CO}_{2}$ output from desertified sandy land in China. Atmospheric Environment 35, 5915-5921.

Dutt, V., Gonzalez, C., 2011. Human control of climate change, Climatic Change doi: 10.1007/s10584-011-0202-x.

Elhadi, E.M., Zomrawi, N., 2010. Landscape change and sandy desertification monitoring and assessment: a case study in Northern Shaanxi Province, China. Journal of American Science 6(2), 46-53.

Elhag, M.M., 2006. Causes and impact of desertification in the butana area of Sudan. University of the Free State. 53-55.

Elmzoughi, A., Zribi, M., Abdelfattah, R. and Belhadj, Z., 2008. Using long term NOAA-AVHRR NDVI time-series data for desertification monitoring in South Tunisia. In: Proceedings 3rd International Conference on Information and Communication Technologies: From Theory to Applications.

Fensholt, R., Proud, S.R., 2012. Evaluation of Earth Observation based global long term vegetation trends-Comparing GIMMS and MODIS global NDVI time series. Remote Sensing of Environment 119, 131-147.

Frankenberg, C., Meirink, J.F., Weele, M., Platt, U., Wagner, T., 2005. Assessing methane emissions from global space-borne observations. Science 308, 1010-1041.

Gao, X., Huete, A.R., Didan, K., 2003. Multisensor comparisons and validation of MODIS vegetation indices at the semiarid Jornada experimental range. Ieee Transactions on Geoscience and Remote Sensing 41(10), 2368-2381.

Guo, M., Wang, X., Liu, Y., Li, J., Wang, H., Matsuoka, N., Tani, H., 2012. The effects of sand dust storms on greenhouse gases. International Journal of Remote Sensing 33(21), 6838-6853.

Haboudane, D., Bonn, F., Royer, A., 2002. Land degradation and erosion risk mapping by fusion of spectrally based information and digital geomorphometric attributes: International Journal of remote sensing 23, 3795-3820.

Hassan, I.E., 2004. Desertification monitoring using remote sensing technology. International Conference on Water Resources and Arid Environment 21, 1-15.

Hengl, T., Heuvelink, G.B.M., Tadic, M.P. and Pebesma, E.J., 2012. Spatio-temporal prediction of daily temperatures using time-series of MODIS LST images. Theoretical and Applied Climatology 107(1-2), 265-277.

Hulme, M., Kelly, M., 1993. Exploring the links between desertification and climate change. Environment: Science and Policy for Sustainable Development 35(6) 4-45. DOI:10.1080/00139157.1993.9929106.

IPCC, 2011. Renewable Energy Sources and Climate Change Mitigation. In: Climate Change 2007: The Physical Science Basis. Contribution of Working Group I to the Fourth Assessment Report of the Intergovernmental Panel on Climate Change, Edenhofer, O., Madruga, R.P., Sokona, Y., Seyboth, K., Eickemeier, P., Matschoss, P., Hansen, G., Kadner, S., Schlömer, S., Zwickel, T., Stechow, C. (Eds.), Cambridge University Press, New York, pp. 1088. 
Inubushi, K., Furukawa, Y., Hadi, A., Purnomo, E., Tsuruta, H., 2003. Seasonal changes of $\mathrm{CO}_{2}, \mathrm{CH}_{4}$ and $\mathrm{N}_{2} \mathrm{O}$ fluxes in relation to land-use change in tropical peatlands located in coastal area of South Kalimantan. Chemosphere 52, 603-608.

Jackel, U., Schnell, S., Conrad, R., 2001. Effect of moisture, texture and aggregate size of paddy soil on production and consumption of $\mathrm{CH}_{4}$. Soil Biology and Biochemistry 33, 965-971.

Jiang, C.S., Wang, Y.S., Hao, Q.J., Song, C.C., 2009. Effect of land-use change on $\mathrm{CH}_{4}$ and $\mathrm{N}_{2} \mathrm{O}$ emissions from fresh water marsh in Northeast China. Atmospheric Environment 43, 3305-3309.

Keppler, F., Hamilton, J.T.G., Brass, M., Rockmann, T., 2006. Methane emissions from terrestrial plants under aerobic conditions. Nature 409, 187-191.

Langer, M., Westermann, S., Boike, J., 2010. Spatial and temporal variations of summer surface temperatures of wet polygonal tundra in Siberia-implications for MODIS LST based permafrost monitoring. Remote Sensing of Environment 114(9), 2059-2069.

Louis, V.S.T., Kelly, C.A., Duchemin, E., Rudd, J.W.M., Rosenberg, D.M., 2000. Reservoir surfaces as sources of greenhouse gases to the atmosphere: A global estimate. Biological Science 50(9), 766-775.

Mielnick, P., Dugas, W.A., Mitchell, K., Havstad, K., 2005. Long-term measurements of $\mathrm{CO}_{2}$ flux and evapotranspiration in a Chihuahuan desert grassland, Journal of Arid Environments 60, 423-436.

Momeni, M., Saradjian, M.R., 2007. Evaluating NDVI-based emissivities of MODIS bands 31 and 32 using emissivities derived by Day/Night LST algorithm. Remote Sensing of Environment 106(2), 190-198.

Myneni, R.B., Keeling, C.D., Tucker, C.J., Asrar, G., Nemani, R.R., 1997. Increased plant grow thin the northern high latitudes from1981 to 1991. Nature 386, pp. 698-701.

Oechel, W.C., Vourlitis, G., Hastings, S.J., Bochkarev, S.A., 1995. Change in arctic $\mathrm{CO}_{2}$ flux over two decades: effects of climate change at Barrow, Alaska, Ecological Applications 5(3), 846-855.

Ojanen, P., Minkkinena, K., Alm, J., Penttilä, T., 2010. Soil-atmosphere $\mathrm{CO}_{2}, \mathrm{CH}_{4}$ and $\mathrm{N}_{2} \mathrm{O}$ fluxes in boreal forestry-drained peatlands. Forest Ecology and Management 260, 411-421.

Parker, R., Boesch, H., Cogan, A., Fraser, A., Feng, L., Palmer, P.I., Messerschmidt, J., Deutscher, N., Griffith, D.W.T., Notholt, J., Wennberg, P.O., Wunch, D., 2011. Methane observations from the Greenhouse Gases Observing SATellite: Comparison to ground-based TCCON data and model calculations. Geophysical Research Letters 38 , L15807. doi:10.1029/2011GL047871.

Reuter, M., Buchwitz, M., Schneising, O., Heymann, J., Bovensmann, H., Burrows J.P., 2010. A method for improved SCIAMACHY $\mathrm{CO}_{2}$ retrieval in the presence of optically thin clouds. Atmospheric Measurement Techniques 3, $209-232$.

Rutherford, M.C., 1980. Annual plant production-precipitation relations in arid and semi-arid regions. South African Journal of Science 76, 53-56.

Schneider, J., Grosse, G., Wagner, D., 2009. Land cover classification of tundra environments in the Arctic Lena Delta based on Landsat 7 ETM+ data and its application for upscaling of methane emissions. Remote Sensing of Environment 113, 380391.

Schneider, K., Huisman, J.A., Breuer, L., Frede, H.G., 2008. Ambiguous effects of grazing intensity on surface soil moisture: A geostatistical case study from a steppe environment in Inner Mongolia, PR China. Journal of Arid Environments 72, 1305-1319 
Schneising, O., Buchwitz, M., Reuter, M., Heymann, J., Bovensmann, H., Burrows J.P., 2011. Long-term analysis of carbon dioxide and methane column-averaged mole fractions retrieved from SCIAMACHY. Atmospheric Chemistry and Physics 11, $2863-2880$.

Schuur, E.A.G., Bockheim, J., Canadell, J.G., Euskirchen, E., Field, C.B., Goryachkin, S.V., Hagemann, S., Kuhry, P., Lafleur, P.M., Lee, H., Mazhitova, G., Nelson, F.E., Rinke, A., Romanovsky, V.E., Shiklomanov, N., Tarnocai, C., Venevsky, S., Vogel, J.G. Zimov, S.A., 2009. Vulnerability of permafrost carbon to climate change: Implications for the global carbon cycle. BioScience 58(8), pp. 701-714.

Stellmes, M., Udelhoven, T., Roder, A., Sonnenschein, R., Hill, J., 2010. Dryland observation at local and regional scaleComparison of Landsat TM/ETM+ and NOAA AVHRR time series. Remote Sensing of Environment 114, $2111-2125$.

Sun, Y.L., 2001. The study on $\mathrm{CO}_{2}$ of karst eco-system of vertical zone in Jinfo Mountain in summer. Southwest Normal University. pp. 1-5. (in Chinese)

Wan, Z., 1999. MODIS Land-Surface Temperature Algorithm Theoretical Basis Document (LST ATBD) Version 3.3. DOI: citeulike-article-id:777547.

Wan, Z.M., 2008. New refinements and validation of the MODIS Land-Surface Temperature/Emissivity products. Remote Sensing of Environment 112(1), 59-74.

Wessels, K.J., Prince, S.D., Frost, P.E., Vanzyl, D., 2004. Assessing the effects of human-induced land degradation in the former homelands of northern South Africa with a 1km AVHRR NDVI time-series. Remote Sensing of Environment 91, $47-67$.

Wu, P., Shi, P., 2011. An estimation of energy consumption and $\mathrm{CO}_{2}$ emissions in tourism sector of China. Journal of Geographical Sciences 21(4), 733-745.

WMO Greenhouse Gas Bulletin, 2004-2010. Available online http://www.wmo.int/pages/prog/arep/gaw/ghg/ghgbull06_en.html (accessed April 2012).

Xie, H., Li, S., Jiang, F., Wang, T.J., 2008. Methane emissions from terrestrial vegetation in China and its impact on lower ropospheric methane concentration. Chinese Science Bulletin 53(19), 2365-2370. (in Chinese)

Yoshida, Y., Ota, Y., Eguchi, N., Kikuchi, N., Nobuta, K., Tran, H., Morino, I., Yokota, T., 2011. Retrieval algorithm for CO 2 and $\mathrm{CH}_{4}$ column abundances from short-wavelength infrared spectral observations by the Greenhouse gases observing satellite. Atmospheric Measurement Techniques 4, 717-734.

Zafar, A., Uriel, S., David, N., Robin, W., 2005. Ecosystems and human well-being, Desertification Synthesis. World Resources Institute, Washington, DC. pp. 15-21.

Zhang, J.Y., Dong, W.J., Fu, C.B., 2005. Impact of land surface degradation in northern China and southern Mongolia on regional climate. Chinese Science Bulletin 50(1), 75-81. 
Table 1. The accuracy of SCIAMACHY WFM-DOAS data set from 2003 to 2009

\begin{tabular}{|c|c|c|c|c|c|c|c|}
\hline & & Ulaan Uul & SCIAMACHY & Error & Mt. Waliguan & SCIAMACHY & Error \\
\hline \multirow{7}{*}{$\mathrm{XCO}_{2}$} & 2003 & 377.67 & 378.28 & $0.16 \%$ & 375.58 & 379.60 & $1.07 \%$ \\
\hline & 2004 & 378.71 & 383.17 & $1.18 \%$ & 377.16 & 374.53 & $-0.70 \%$ \\
\hline & 2005 & 380.24 & 382.63 & $0.63 \%$ & 379.66 & 381.91 & $0.59 \%$ \\
\hline & 2006 & 383.70 & 384.87 & $0.31 \%$ & 382.99 & 381.02 & $-0.51 \%$ \\
\hline & 2007 & 384.74 & 391.04 & $1.64 \%$ & 385.04 & 391.02 & $1.55 \%$ \\
\hline & 2008 & 386.92 & 391.84 & $1.27 \%$ & 385.89 & 385.15 & $-0.19 \%$ \\
\hline & 2009 & 388.40 & 388.38 & $0.00 \%$ & 388.55 & 389.75 & $0.31 \%$ \\
\hline \multirow[t]{4}{*}{ Ave. error } & & & & $0.74 \%$ & & & $0.30 \%$ \\
\hline & 2003 & 1859.53 & 1780.07 & $-4.27 \%$ & 1834.57 & 1742.01 & $-5.05 \%$ \\
\hline & 2004 & 1859.39 & 1767.60 & $-4.94 \%$ & 1832.22 & 1743.14 & $-4.86 \%$ \\
\hline & 2005 & 1855.98 & 1771.39 & $-4.56 \%$ & 1830.63 & 1760.21 & $-3.85 \%$ \\
\hline \multirow[t]{4}{*}{$\mathrm{XCH}_{4}$} & 2006 & 1855.87 & 1787.86 & $-3.66 \%$ & 1828.14 & 1784.78 & $-2.37 \%$ \\
\hline & 2007 & 1858.69 & 1787.69 & $-3.82 \%$ & 1829.77 & 1793.48 & $-1.98 \%$ \\
\hline & 2008 & 1867.31 & 1809.27 & $-3.11 \%$ & 1855.57 & 1804.68 & $-2.74 \%$ \\
\hline & 2009 & 1872.92 & 1788.50 & $-4.51 \%$ & 1843.05 & 1802.82 & $-2.18 \%$ \\
\hline Ave. error & & & & $-4.12 \%$ & & & $-3.29 \%$ \\
\hline
\end{tabular}




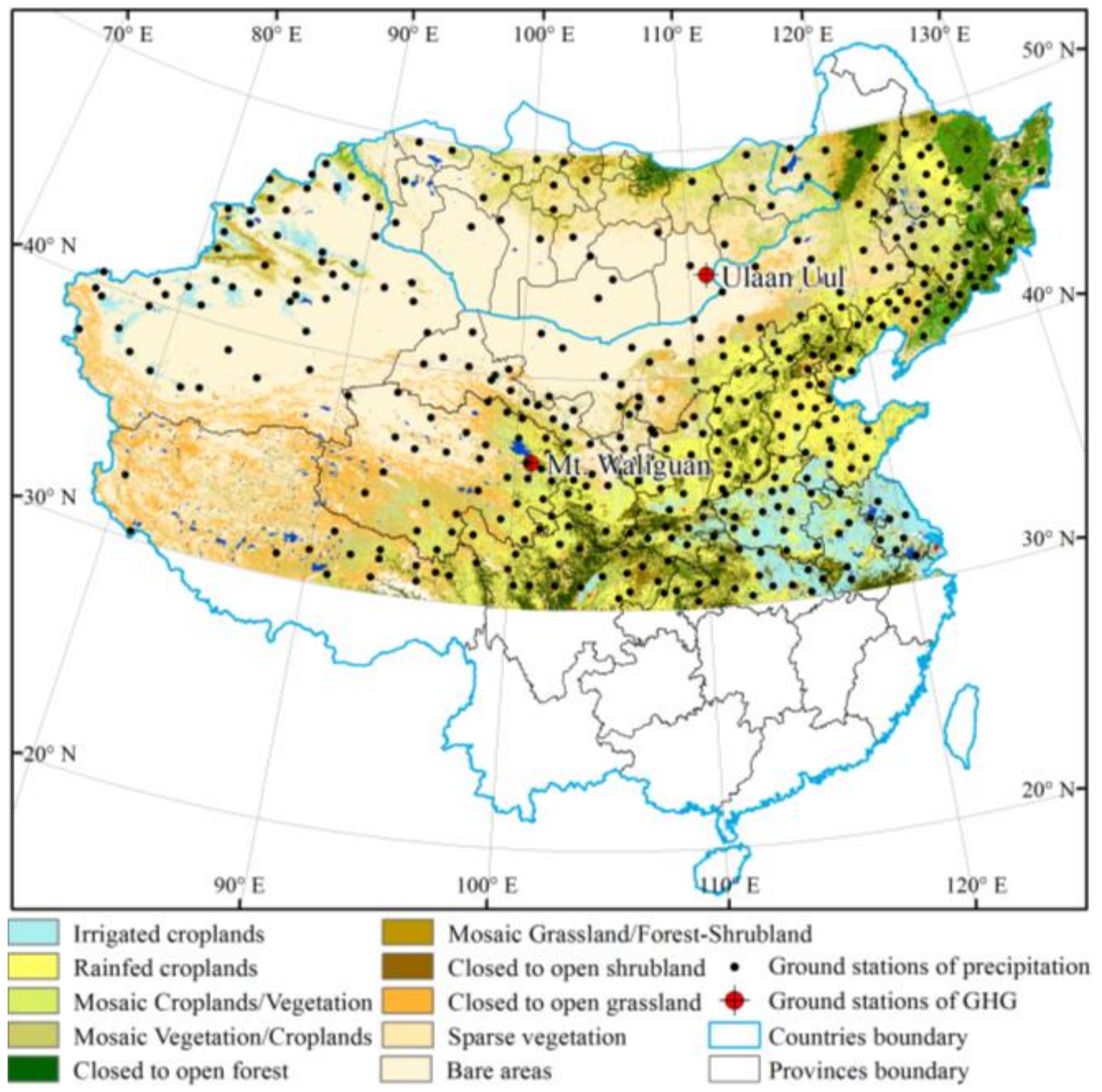

Fig. 1. Study region location. The areas that covered by land cover image are the study region. The land cover data were downloaded from website of ESA (http://ionia1.esrin.esa.int/). Here, we have not list all the land cover legends. 


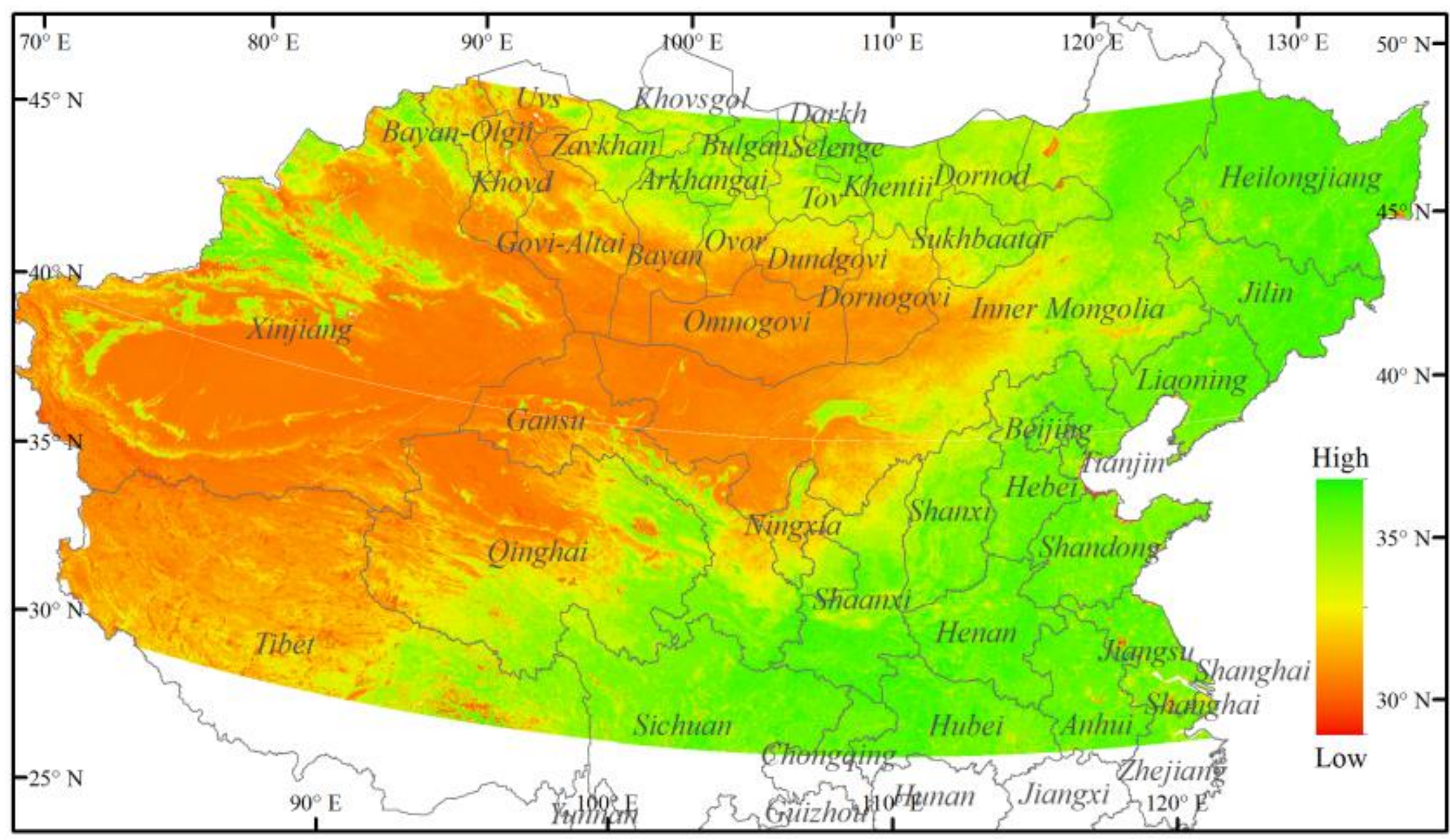

Fig. 2. NDVI data of growing season in 2010. In present study we defined Julian calendar days 161 to 257 as the growing season. 


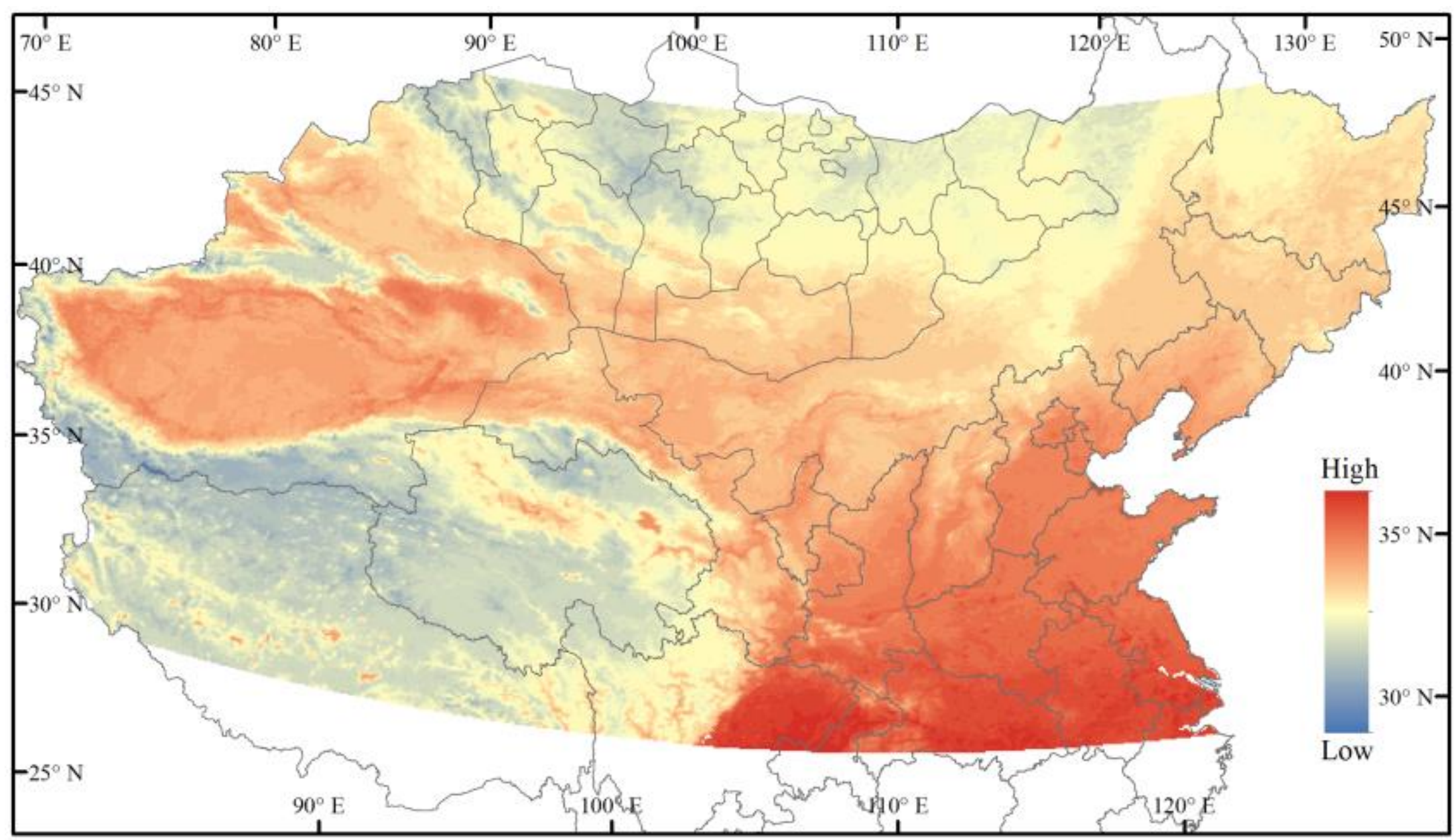

Fig. 3. LST data from MODIS in 2010. Average value of the monthly LST data (MOD11C3) was used in present study. 


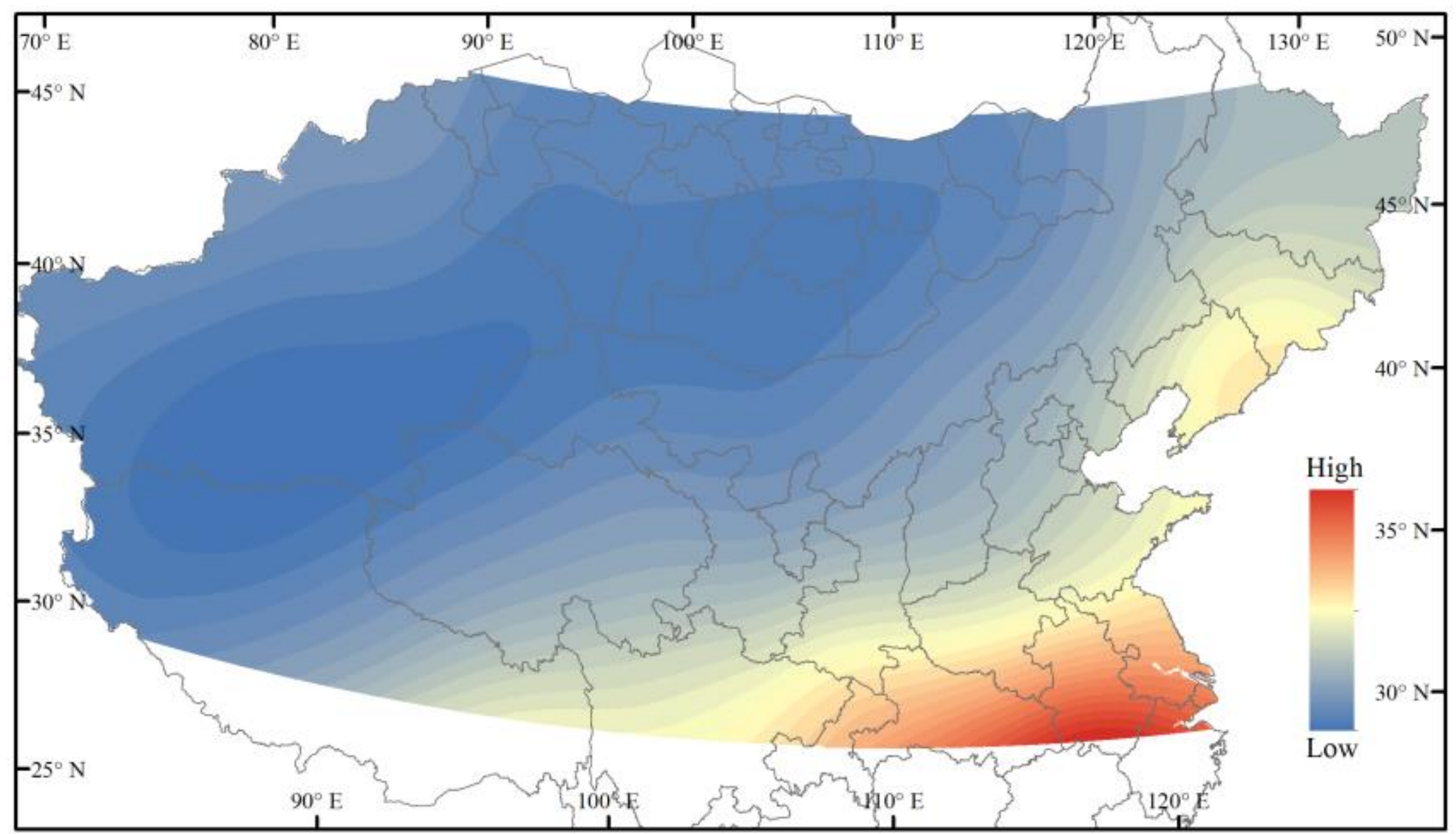

Fig. 4. Precipitation interpolation map based on 214 ground stations data in China and Mongolia and employed Ordinary Kriging methods. 


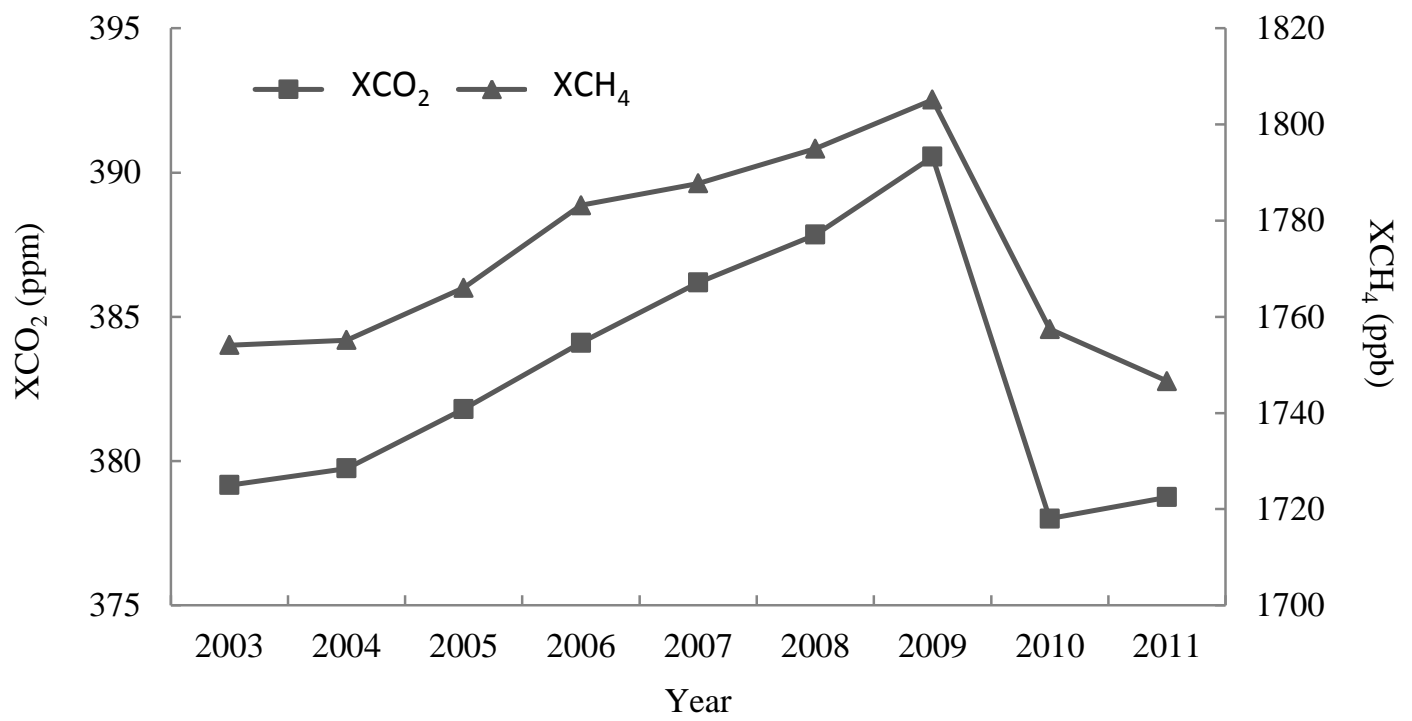

Fig. 5. $\mathrm{XCO}_{2}$ and $\mathrm{XCH}_{4}$ changes from 2003 to 2011, data from SCIAMACHY (2003-2009) and GOSAT (2010-2011) that covered the study area (regions that covered by the land cover image).

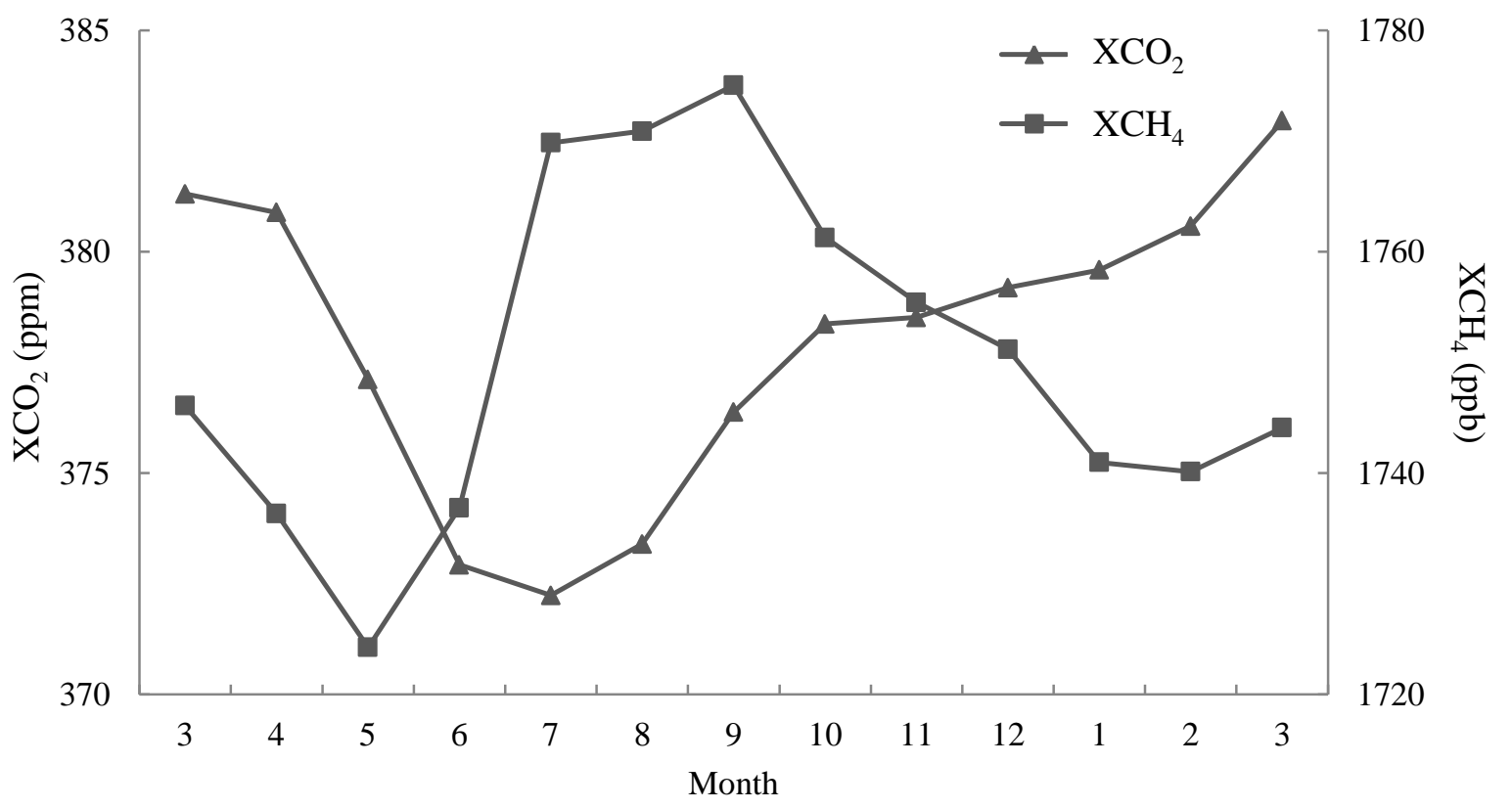

Fig. 6. The monthly $\mathrm{CO}_{2}$ and $\mathrm{CH}_{4}$ concentrations from March 2010 to March 2011. 


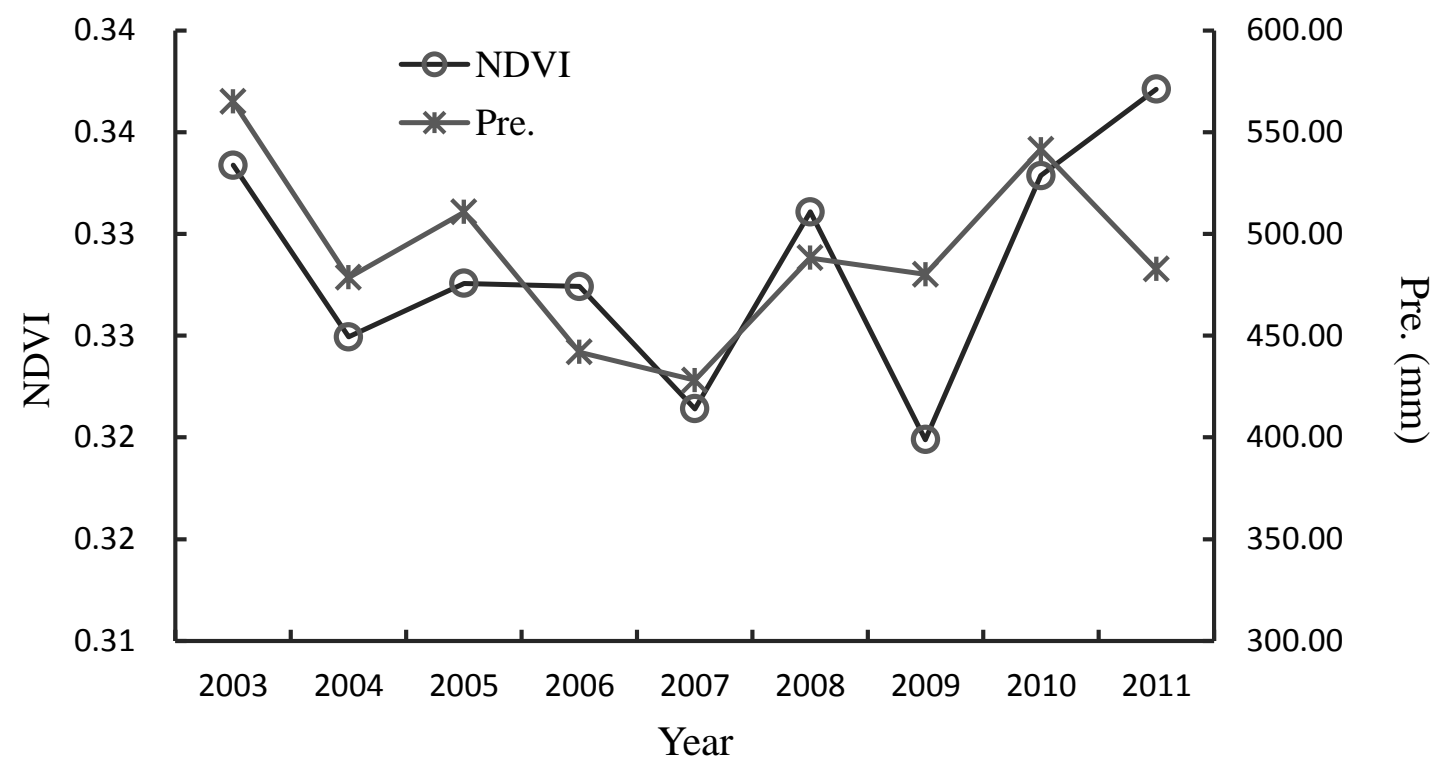

Fig. 7. Annual MODIS Terra NDVI and annual precipitation from 2003 to 2011. 

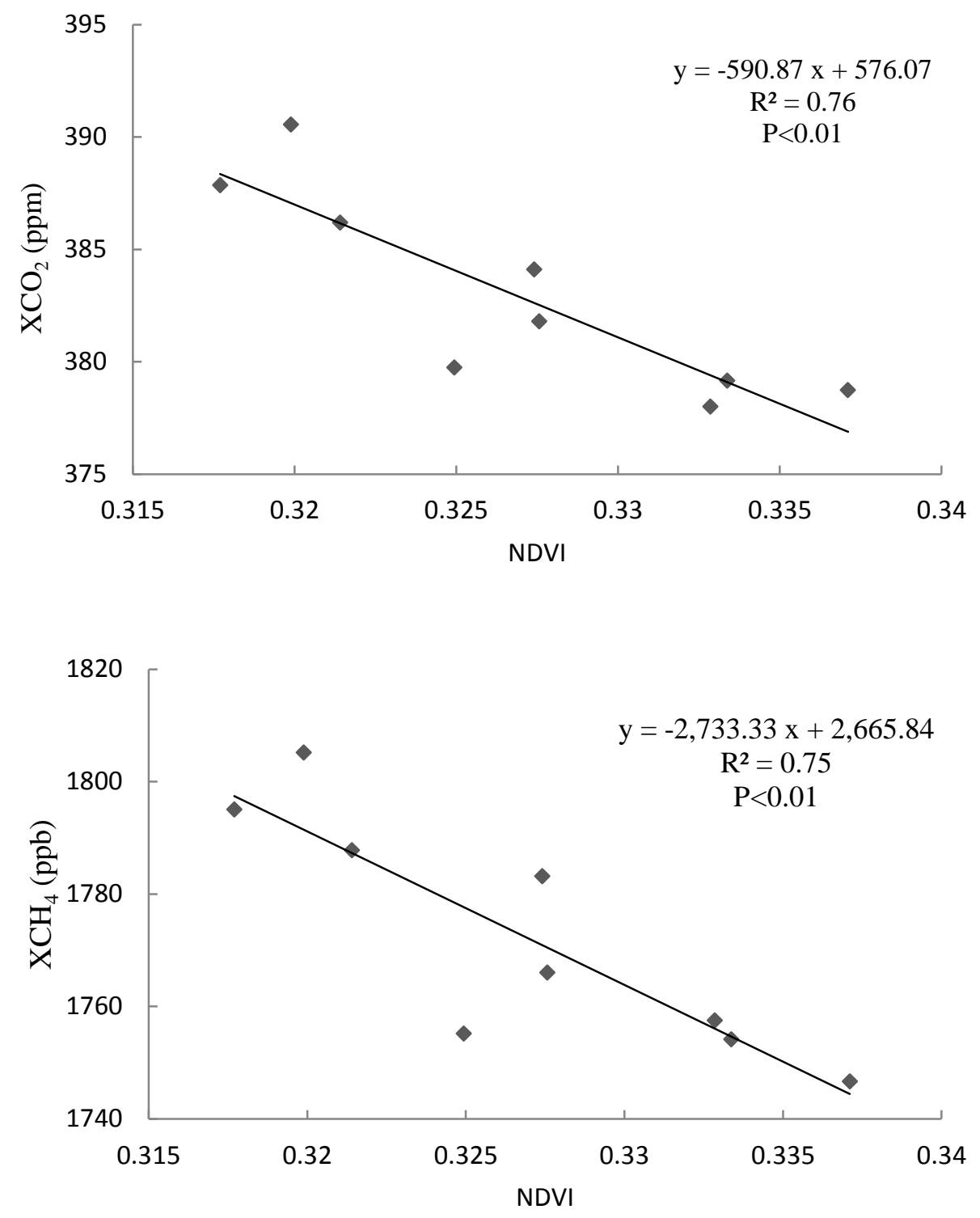

Fig. 8. The correlation coefficient between NDVI and GHG concentrations. 

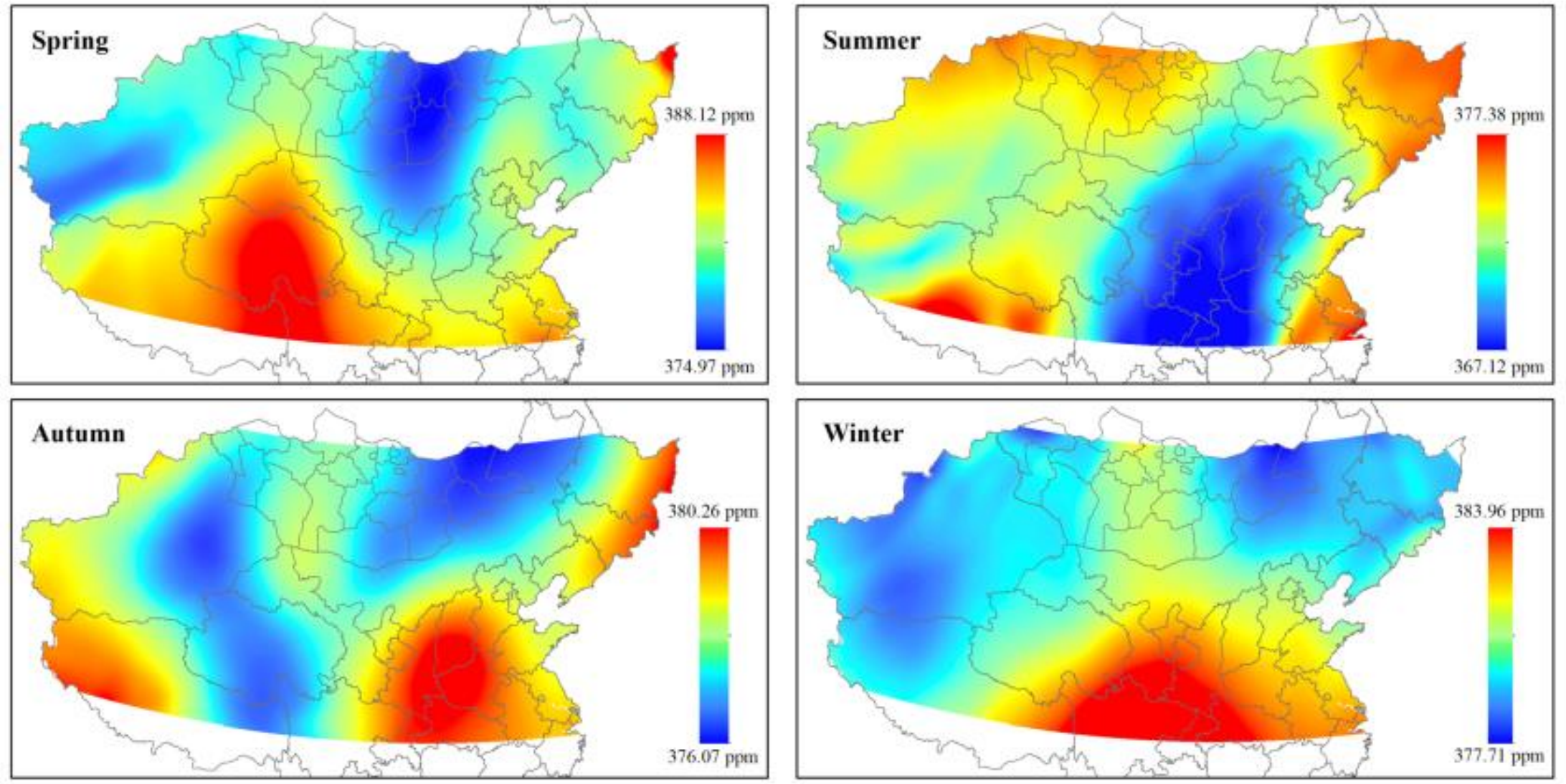

Fig. 9. Spatial distribution of $\mathrm{CO}_{2}$ concentration in spring, summer, autumn and winter. 

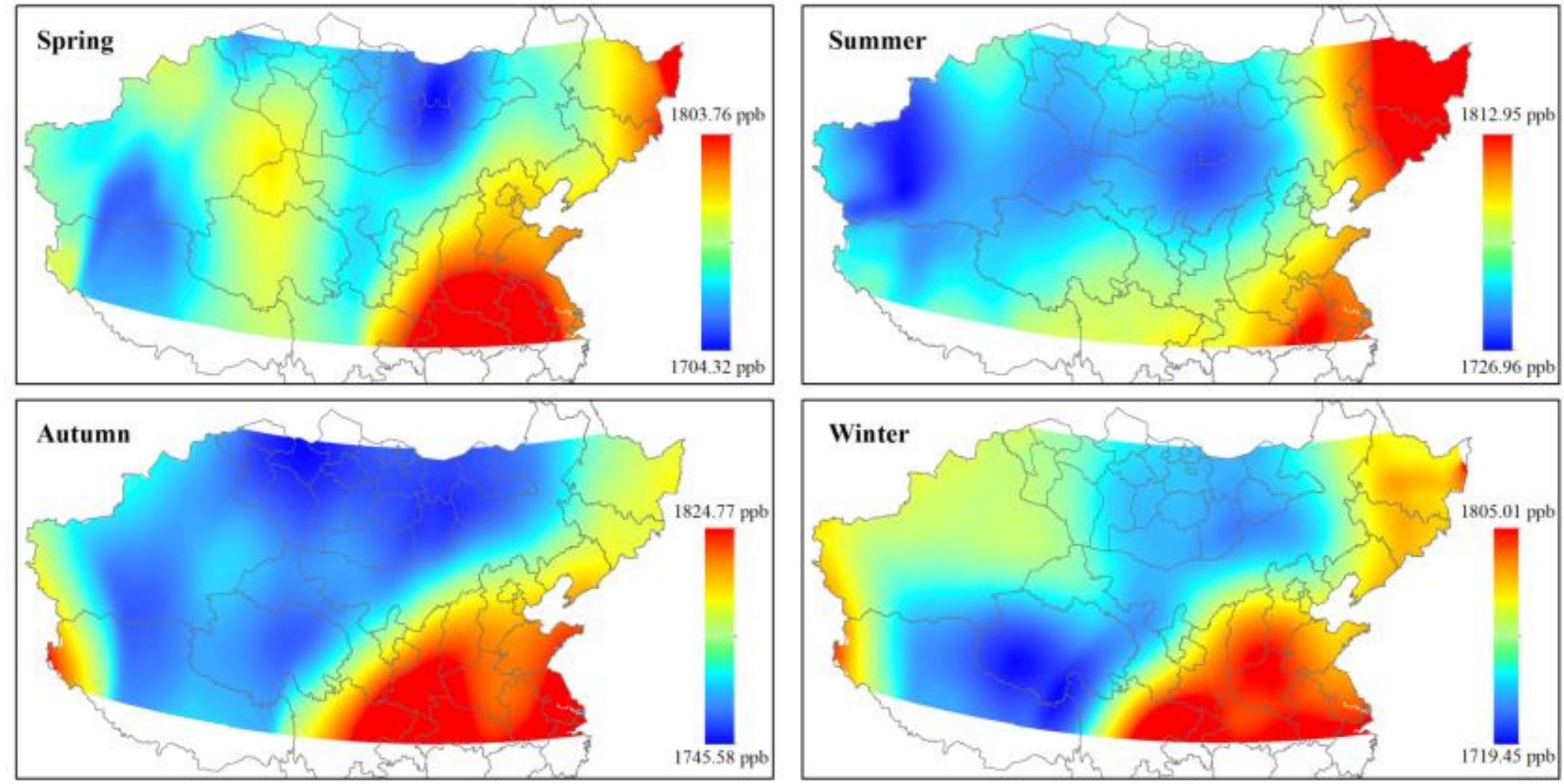

Fig. 10. Spatial distribution of $\mathrm{CH}_{4}$ concentration in spring, summer, autumn and winter. 